\title{
Students' Thinking Process in Solving Mathematical Problems in Build Flat Side Spaces of Material Reviewed from Adversity Quotient
}

\author{
Indra Sari ${ }^{1, *}$, Marwan $^{1}$, and Hajidin ${ }^{1}$ \\ ${ }^{1}$ Master of Mathematisc Education, Syiah Kuala University, Banda Aceh, Indonesia \\ *Corresponding author: tinsar_suari@yahoo.co.id
}

\section{ARTICLE HISTORY}

Received : 13 June 2019

Revised : 22 August 2019

Accepted : 13 October 2019

\section{KEYWORDS}

Adversity quotient; Build flat side space; Problem solving; Thinking process;

\begin{abstract}
Mathematical achievement in problem solving is not yet as expected. This is due to strategies that have not accommodated the situation of students. Adversity quontient is the state of the student who needs to get the attention of the teacher so that the learning strategy is expected to be appropriate. This research aims to describe the thinking process of MTs Darul Hikmah students in solving mathematical problems in build side spaces of material reviewed from adversity quotient. This research is in the form of qualitative. The subject selection was done by giving questionnaires to class VIII MTSS Darul Hikmah students and obtained by each one person from each adversity quotient group. The subjects in this study amounted to two students. Data collection is done through tests and interviews, while data analysis uses qualitative data analysis techniques, namely data reduction, data display and conclusions from each adversity quotient group. The results showed that no class VIII students entered the quitters group and the results of the study also showed that class VIII students consisted of climpers and campers. The process of thinking of MTsS Darul Hikmah students based on adversity quotient varied: students in the climbers category namely 3 of 53 students had conceptual thinking processes, while students in the campers category were 27 of 53 students did not have conceptual, semiceptual, or computational thinking processes.
\end{abstract}

This is an open access article under the CC-BY-SA license.

\section{INTRODUCTION}

Mathematics can familiarize someone to think systematically, scientifically using logic, and increase creativity. The usefulness of mathematics not only gives ability in quantitative calculations, but also in structuring the way of thinking, especially in terms of the formation of the ability to analyze, make syntheses, conduct evaluations to solve problems (Dahrim, 1993).

Mathematics is closely related to problem solving (Ulya, 2015). Zevenbergen, Dole, \& Wright (2004) states that solving problems requires adequate understanding and knowledge, and has a variety of strategies that can be chosen when facing different problems. Problem solving skills for students need to be sought so that students are able to find solutions to various problems, both in the field of mathematics and problems in increasingly complex daily life (Effendi, 2012). Krulik \& Rudnick (1995) defines problem-solving abilities as a means for individuals to use previously owned knowledge and abilities to be synthesized and applied to new and different situations.

Thinking is always related to problems that arise from the present, past and maybe problems that have not happened. The problem solving process is called the thought process (Ahmadi, 2003). The process of thinking is a mental activity or a process that occurs in the mind of students when students are faced with a new knowledge or problem that is happening and looking for a way out of these problems. The process of thinking in learning mathematics is a mental activity that is in the minds of students, so (Herawati, 1994) states that to find out how students think processes can be observed through the process of how to do tests and results written in order. In addition, it was added with in-depth interviews about how it works.

Until now the learning process carried out by teachers tends to be student-centered which has an impact on student achievement. One obstacle is the low ability of students which is characterized by: students having problems in analyzing problems, designing a problem solving plan, doing calculations mainly related to apperception material (Komariah, 2011). The teaching and learning process still tends to be teacher centered and not many have applied student centered. Meanwhile most teachers in teaching still lack attention to students' thinking abilities and the teaching methods used are less varied (Muldash, 2011).

One of the difficulties faced by students in learning mathematics is in solving geometric problems (Hoffer, 1981). In the process of solving questions about geometry students are - 
required to think in completing them. Various ways that students do to solve problems in mathematics are a problem that must be studied more deeply. As an educator, this must be realized and understood thoroughly about how students understand and work on the problem of building a flat side space (Masfingatin, 2014). Polya (1973) offered a problem solving strategy consisting of four steps, namely understanding the problem, devising a plan, carrying out the plan, and looking back. In solving problems, the thoughts and approaches used in the solution process are more important than the answers obtained, in other words, how the results achieved are far more important (Mayer, Sims, \& Tajika, 1995). With this belief, it is hoped that seriousness will emerge to be more sensitive and careful in trying to find and develop the potential students have in learning mathematics (Masfingatin, 2014).

Some teachers believe that problem solving skills develop automatically from mastering numeracy skills. According to (Lenchner, 2005), this is not entirely true. Problem solving is a skill that needs to be taught and the teacher must strive for it. These efforts can be done through learning comprehensive problem solving skills, which include steps or strategies in solving problems.

Students' problem solving abilities are different influenced by their ability to think. Thinking ability known as adverstiy quotient. The ability of a person to use his intelligence to direct, change the way he thinks and acts when facing obstacles and difficulties. Adversity quotient helps individuals strengthen their abilities and perseverance in facing the challenges of everyday life while still adhering to principles and dreams regardless of what is happening (Nashori, 2007; Stoltz, 2007).

Adverstiy quotient can be divided into climbers, campers, and quitters. Climbers are those who are always optimistic, see opportunities, see gaps, see the hope behind despair, always eager to move forward. Climbers are able to make small noktas considered trivial as a bright light of success (Agustian, 2001). Campers are those who are satisfied with sufficiency and do not want to develop themselves. This type is a group that is a little more numerous, namely trying to fulfill security needs and security (Stoltz, 2007). Whereas quitters are those who choose to leave, avoid obligations, retreat and stop when facing difficulties (Agustian, 2001). Information about adverstiy quotient of students reflects the ability of the strategy chosen in dealing with the problems of students with adverstiy quotient of certain groups will be able to tend until the problem can be solved while other group students tend to avoid (Stoltz, 2007). Information about Adverstiy Quotient students is very important for teachers in determining learning strategies. Accuracy in choosing the level of learning according to the conditions of students will be able to impose student achievement.

Table 1 Indicator of the Thinking Process (Zuhri, 1998)

\begin{tabular}{|c|c|c|}
\hline Conceptual thinking Process & Semiconseptual thinking process & Computational thinking process \\
\hline $\begin{array}{l}\text { - Students are able to express what is } \\
\text { known in a question with their own } \\
\text { language or change it in a mathematical } \\
\text { sentence (B1.1) }\end{array}$ & $\begin{array}{l}\text { - Students are less able to express } \\
\text { what is known in a question with } \\
\text { their own language or change it in a } \\
\text { mathematical sentence (B2.1) }\end{array}$ & $\begin{array}{l}\text { - Students are not able to express what is } \\
\text { known in a question with their own } \\
\text { language or change it in a mathematical } \\
\text { sentence (B3.1) }\end{array}$ \\
\hline $\begin{array}{l}\text { - Students are able to express what is } \\
\text { asked in a question with their own } \\
\text { language or change it in a mathematical } \\
\text { sentence (B1.2) }\end{array}$ & $\begin{array}{l}\text { - Students are less able to say what is } \\
\text { asked in a question with their own } \\
\text { language or change it in a } \\
\text { mathematical sentence (B2.2) }\end{array}$ & $\begin{array}{l}\text { - Students are not able to express what is } \\
\text { asked in a question with their own } \\
\text { language or change it in a mathematical } \\
\text { sentence (B3.2) }\end{array}$ \\
\hline $\begin{array}{l}\text { - Students are able to make a complete } \\
\text { settlement plan (B1.3) }\end{array}$ & $\begin{array}{l}\text { - Students are less able to make a } \\
\text { complete settlement plan (B2.3) }\end{array}$ & $\begin{array}{l}\text { - Students are not able to make a complete } \\
\text { settlement plan (B3.3) }\end{array}$ \\
\hline $\begin{array}{l}\text { - Students are able to state the steps taken } \\
\text { in solving the problem using the concepts }\end{array}$ & - Students are less able to state the & - Students are not able to state the steps \\
\hline
\end{tabular}

One way that can be done to achieve the goal of mathematics learning is to develop educational programs that capabilities can be done through mathematics which can substantially encourage the development of students' thinking abilities. Mathematical concepts are arranged hierarchically, structurally, logically, and systematically starting from the simplest to the most complex concepts, so that it requires good mathematical thinking skills to overcome them (Winarso, 2014).

Thus, the formulation of the problem in this study is how the thinking process of students in Darul Hikmah MTsS in solving mathematical problems in the material builds up flat side space in terms of adversity quotient?

Based on the formulation of the problem, the purpose of this research is to describe the thinking process of the MTsS Darul Hikmah students in solving mathematical problems in the matter of building a flat side space in terms of adversity quotient.

\section{RESEARCH METHODS}

This rsearch uses a type of descriptive research that aims to describe students' thinking processes in solving mathematical problems in the material of building a flat side space. The approach used in this research is a qualitative approach, because this research develops the concept of existing data which is more concerned with processes than results (Moleong, 2016).

This research was conducted on class VIII MTsS Darul Hikmah Aceh Besar in the even semester 2018/2019. The reason for choosing this school is because there are problems in students in solving problems with the material of building a flat side space. The subject selection was done by giving questionnaires to class VIII MTsS Darul Hikmah students and obtained by one individual from each adversity quotient group. The subjects in this study amounted to two students.

Data collection in this study using test and interview techniques, so that the data obtained in the form of test results and interviews. Test techniques are used to collect data on students' thinking processes. The interview technique is used to find data that is not found on the test and to ascertain what the research subject says is the same as what has been done.

The research instrument is in the form of test questions and interview guidelines. The test questions used are in the form of problem solving. The measurement of students 'thinking process is based on the type of students' thinking process, namely: 1) conceptual thinking process, 2) semiceptual thinking process, and 3) computational thinking process. focus on developing thinking skills. The development of these 
that have been studied (B1.4)

- Students are able to re-examine the truth or correct errors from each step of completion so that the correct results are obtained (B1.5) steps taken in solving the problem using the concepts that have been studied (B2.4)

- Students are less able to check the truth or correct errors from each step of completion so that errors often occur (B2.5) taken in solving the problem using the concepts that have been studied (B3.4)

- Students are unable to check or correct the solution made (B3.5)
The data analysis technique used in this study is using qualitative analysis techniques, namely data reduction, data display, and conclution (Miles \& Huberman, 1994). The steps of data analysis in this study are:

1. Data Reduction

At this stage, the researcher summarizes the results of the test and interview data that are valid, simplifies, selects the main points, and focuses on matters that are relevant to the research objectives. So the results obtained will provide a detailed description of the data to be presented. The activities of researchers at this stage are:

a. Transcribe the entire utterance of the student by playing back the interview recording.

b. Select interview records by removing unnecessary parts

c. Re-examine the correctness of the results of the transcription by playing back the recording of the interview results until it is completely clear what the subject expressed in the interview.

d. Typing and compiling the results of transcriptions to facilitate the analysis process.

2. Data Display

At this stage, the researcher presents data which is the result of data reduction. Data on students' thinking processes in mathematical problem solving are categorized

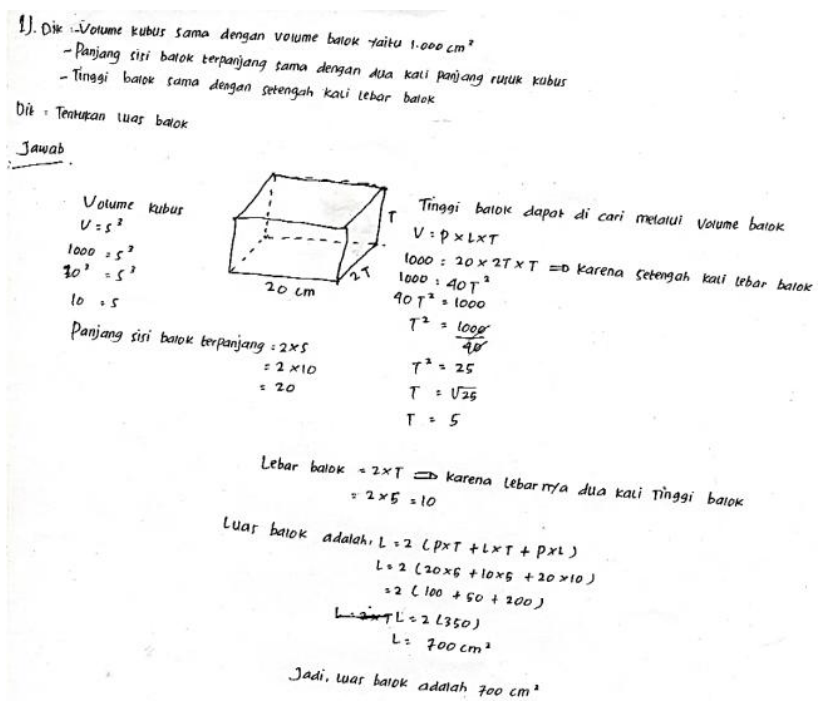

Fig 1. Students answer climbers on the first problem

For the first problem and the equivalent problem with the first problem, climbers are able to declare all known information on the problem, such as the volume of the cube is the volume of the beam, the length of the longest side is twice the length of the cube and the height of the beam is half beam width. Furthermore, climbers can also state what is being asked, which is asked about the problem, namely the area of the beam. and will be presented in the form of narrative texts. The presentation of this data describes the test results and interviews.

3. Conclusion

Withdrawal of conclusions in this study refers to the criteria for the form of testing of the problem proposed. Drawing conclusions aims to describe the thinking process of MTs Darul Hikmah students in solving mathematical problems in the material of building a flat side space.

Check the validity of the data in this study using time triangulation. Time triangulation is done by giving equal questions in different times. Time triangulation in this study was conducted for data validation.

\section{RESULTS AND DISCUSSION}

\subsection{Result}

\section{Climbers Student Thinking Process}

The following is the thought process of students climbers in solving the first problem:

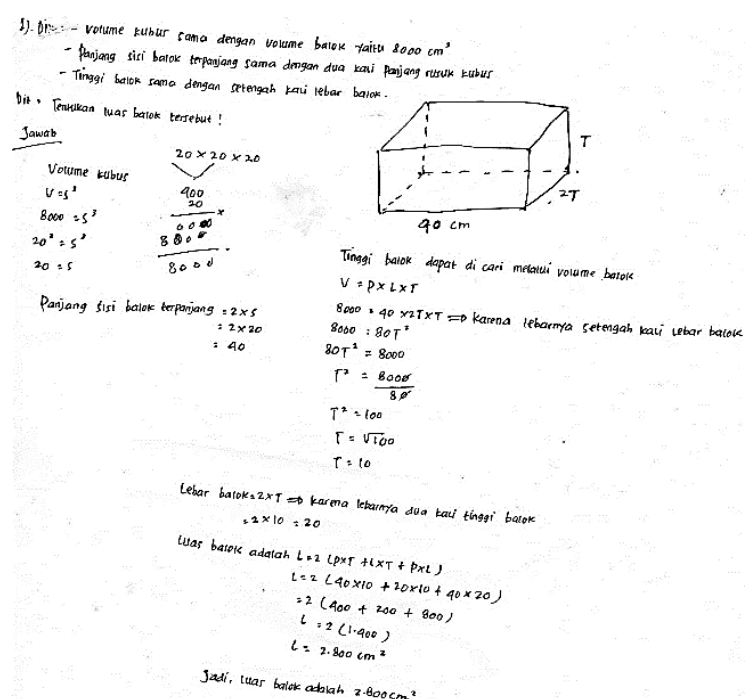

Fig 2. Students climbers answer for equal problems

In addition, climbers students are also able to plan a settlement and implement the settlement plan properly. Then the climbers students are also able to re-check the completion steps that have been done and the resulting answers are also correct.

The following is the thought process of students climbing in solving the second problem: 


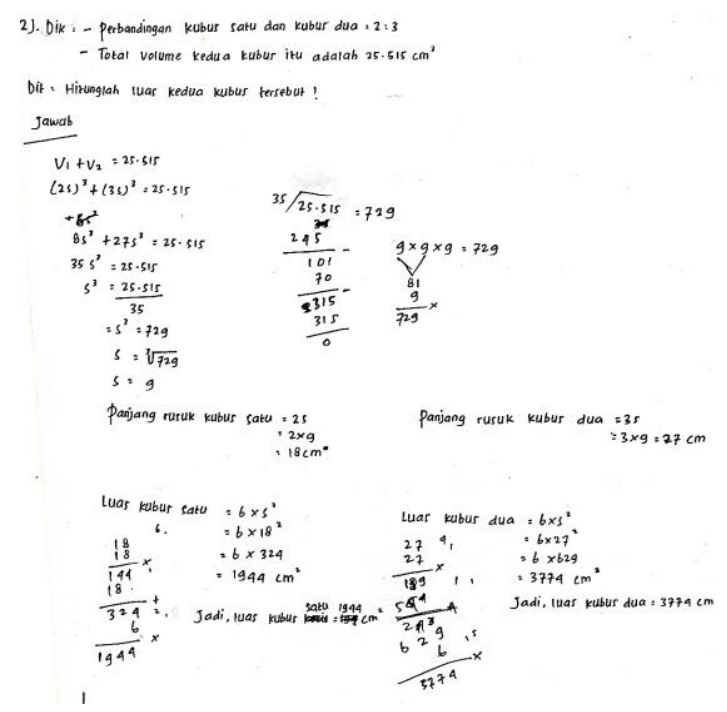

Fig 3. Students answer climbers on the second problem

For the second problem and problems that are equivalent to the second problem, climbers students are able to declare all known information on the problem, such as the comparison of the second rib cube and the number of volumes of the two cubes. Furthermore, climbers students can also state what they are asked to ask about the problem, namely the area of the two cubes. In addition, climbers students are also able to plan a

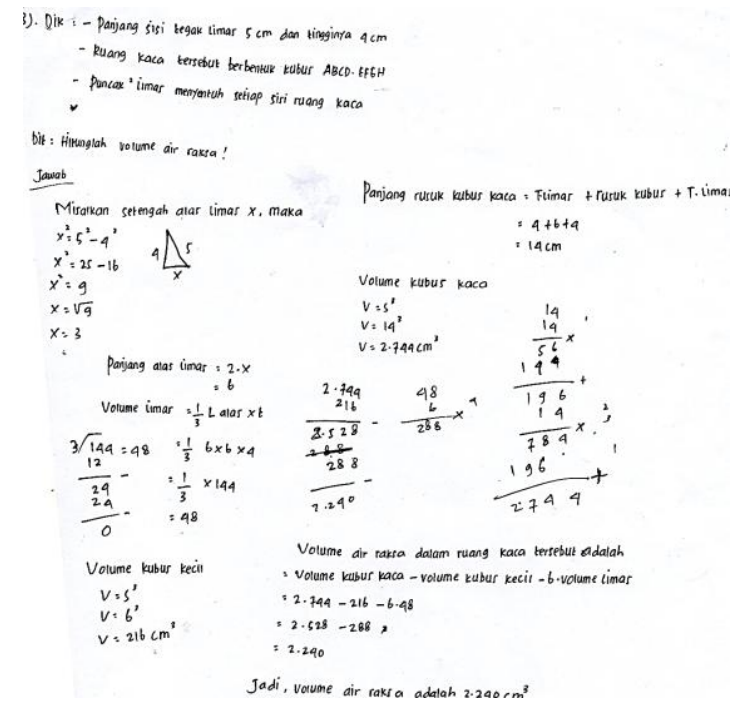

Fig 5. Students answer climbers on the third problem

For the problems of the three climbers students were able to declare all the information known from the question, namely solid decoration in the form of a combination of pyramid and cubes placed in a glass room, the upright length of the pyramid $5 \mathrm{~cm}$ and $4 \mathrm{~cm}$ high, the glass space is ABCD.EFGH and peakpyramid peaks touch each side of the glass room. For problems that are equivalent to the third problem, climbers students are also able to state all the information known in the question, such as solid decoration in the cube in the form of a combination of pyramid and blocks placed in the glass room, the upright side of the pyramid $10 \mathrm{~cm}$ and $6 \mathrm{~cm}$ high. The glass room is a cube $A B C D$. EFGH, pyramid tops touch the side of the beam, and the pyramid pad touches the side of the glass

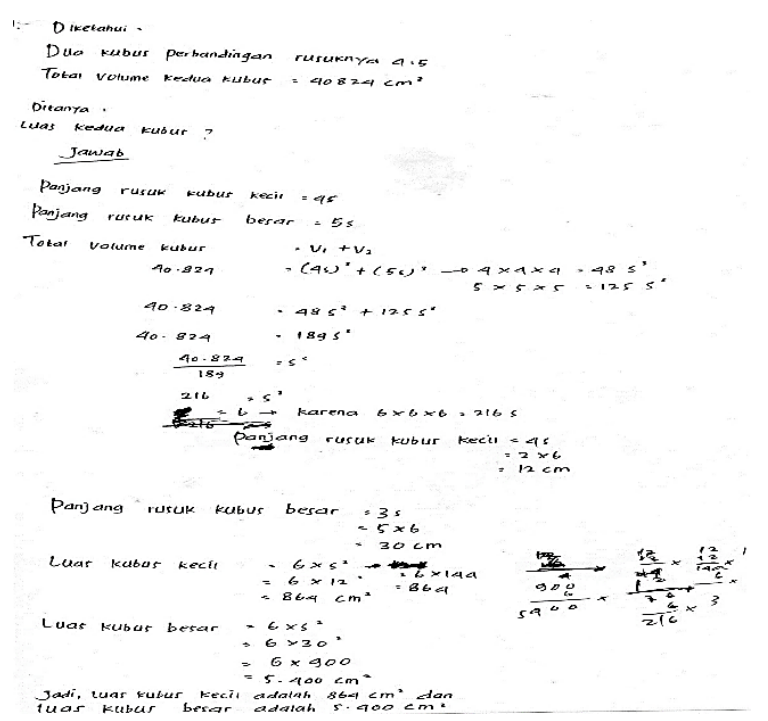

Fig 4. Students climbers answer for equal problems

settlement and implement the settlement plan properly. Then the climbers students are also able to re-check the completion steps that have been done and the resulting answers are also correct.

The following is the thought process of students climbers in solving the third problem:

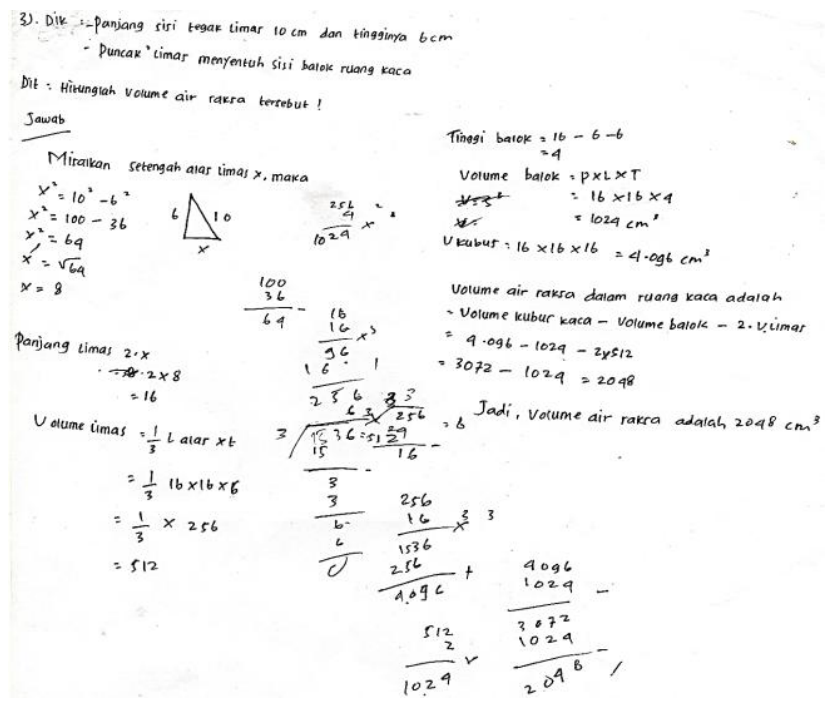

Fig 6. Students climbers answer for equal problems

chamber. Furthermore, climbers students can also state what was asked, which was asked from the question, namely the volume of mercury in the glass room. In addition, climbers students are also able to plan a settlement and implement the settlement plan properly. Then the climbers students are also able to re-check the completion steps that have been done and the resulting answers are also correct.

\section{Campers Student Thinking Process}

The following is the thought process of students campers in solving the first problem: 


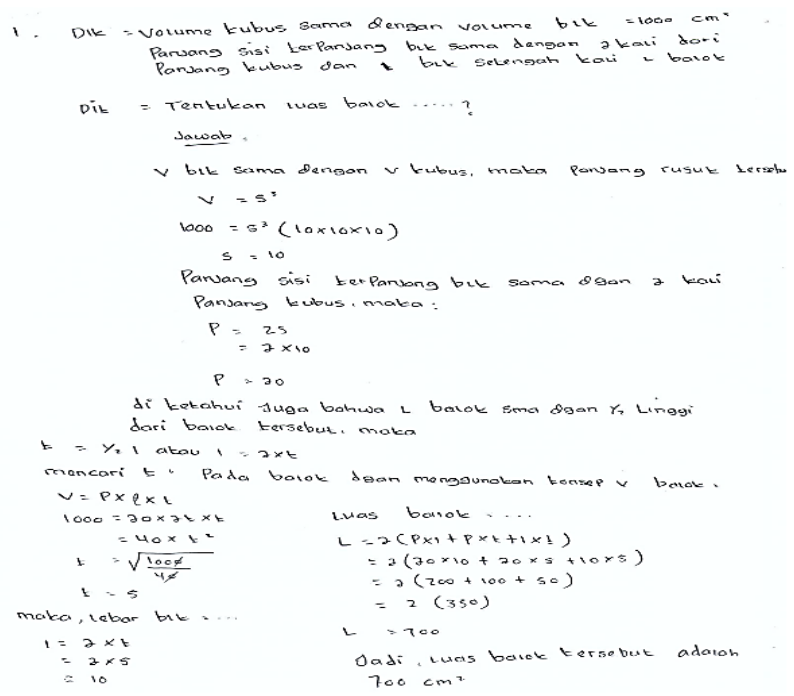

Fig 7. Students answer campers on the first problem

For the first problem and the equivalent problem with the first problem, campers students are able to declare all known information on the problem, such as the volume of the cube is the volume of the beam, the longest side length of the beam is twice the length of the cube and half the height beam width. Furthermore, campers can also state what they are asked to ask about the problem, namely the area of the beam. In addition,

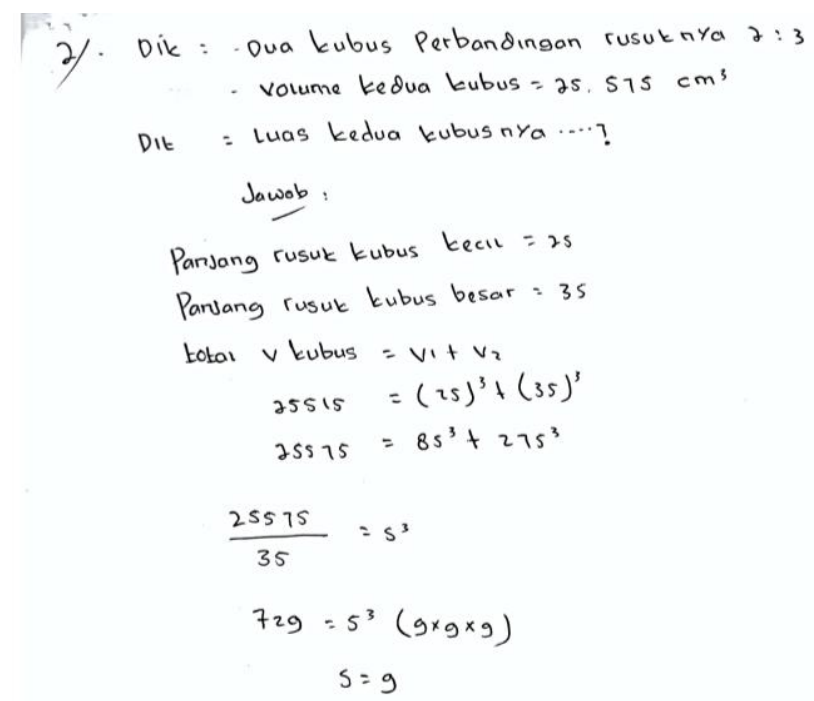

Fig. 9. Students answer campers on the second problem

For the second problem and problems that are equivalent to the second problem, campers students are able to declare all known information on the problem, such as the comparison of the second rib cube and the number of volumes of the two cubes. Furthermore, the campers can also state what they are asked to ask from the question, namely the area of the two cubes. In addition, campers students seem to be less able to plan a settlement and implement the settlement plan properly so that they have not yet obtained the expected final results.

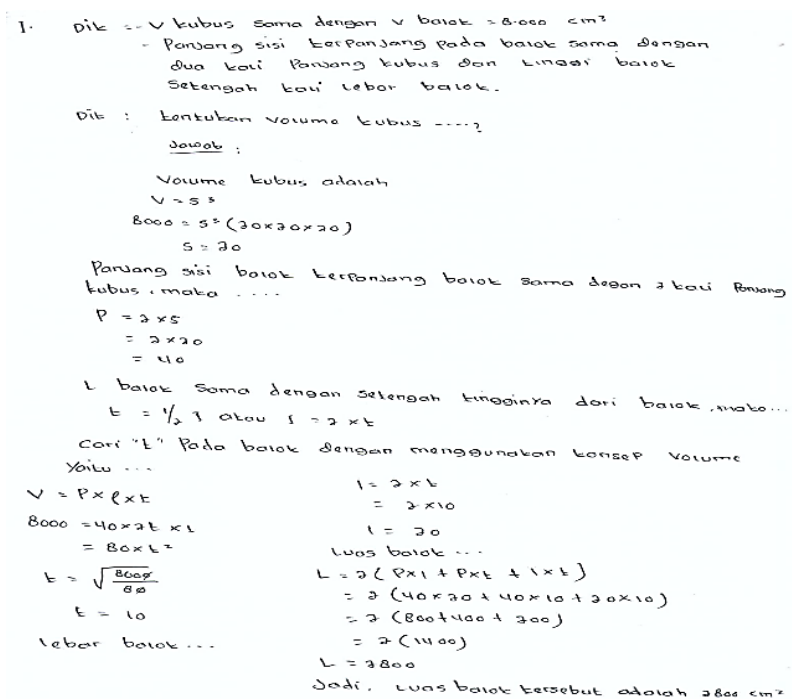

Fig 8. Students campers answer for equal problems

campers students are also able to plan a settlement and implement the settlement plan properly. Furthermore the campers students are also able to re-check the completion steps that have been done and the resulting answers are also correct.

The following is the thought process of students campers in solving the second problem:

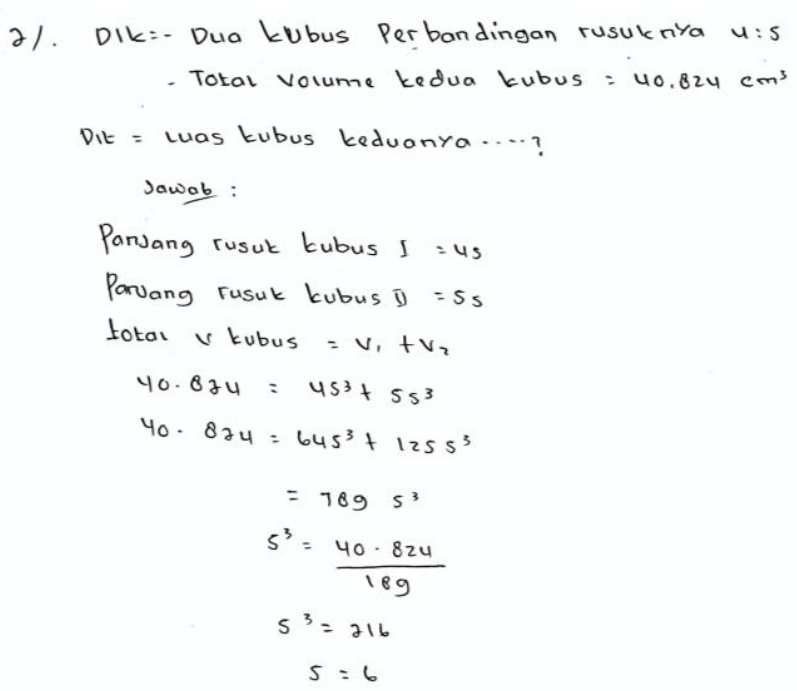

Fig. 10. Students campers answer for equal problems

Furthermore the campers students are also able to re-examine the completion steps that have been done. This is because the steps for resolving the campers students have not been completely finished.

The following is the thought process of students campers in solving the third problem: 


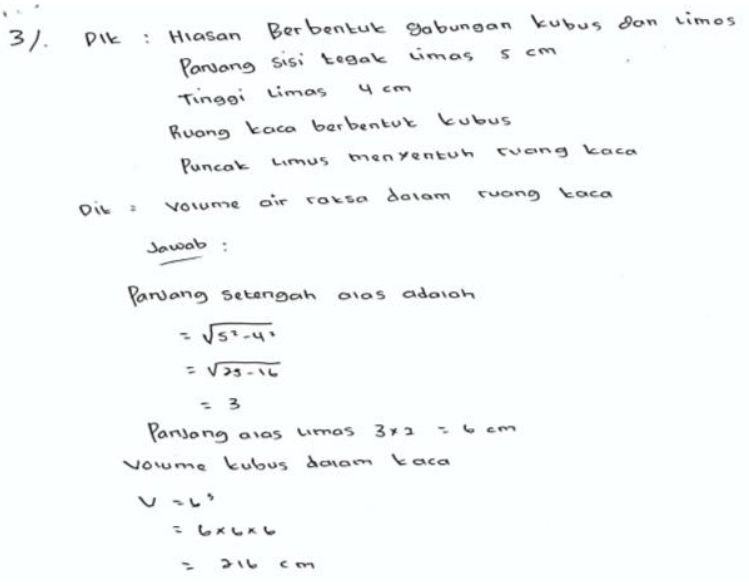

Fig. 11. Students answer campers on the third problem

For the problems of the three campers students were able to declare all the information known from the problem, namely solid decoration in the form of a combination of pyramid and cubes placed in a glass room, the upright length of the pyramid $5 \mathrm{~cm}$ and $4 \mathrm{~cm}$ high, the glass room was cube ABCD. EFGH and peak- pyramid peaks touch each side of the glass room. For problems that are equivalent to the third problem, campers students are also able to state all the information known in the question, such as solid decoration in the cube in the form of a combination of pyramid and blocks placed in the glass room, the upright side of the pyramid $10 \mathrm{~cm}$ and $6 \mathrm{~cm}$ high. The glass room is a cube ABCD. EFGH, pyramid tops touch the side of the beam, and the pyramid pad touches the side of the glass chamber. Furthermore, student clampers can also state what was asked, which was asked from the question, namely the volume of mercury in the glass room. In the third problem and problems that are equivalent to this third problem, campers students are not able to make a settlement plan so that the implementation plan cannot be implemented properly. Furthermore, the cambers students were also unable to re-examine the completion steps because the completion steps had not been completed and had not yet obtained the final results.

\subsection{Discussion}

\section{Climbers Student Thinking Process}

The results of the test analysis and student climbers interview for the first, second, and third problems fulfilled the indicator: able to state what is known in the problem with their own language or change it in mathematical sentences (B1.1), able to express what was asked in the question with their own language change it in a mathematical sentence (B1.2), able to make a complete settlement plan (B1.3), able to state the steps taken in solving the problem using the concepts that have been studied (B1.4), and being able to re-examine the truth or correct error from each step of completion so that the correct result is obtained (B1.5).

Based on the indicators fulfilled and guided by the classification of students' thinking processes, the thinking process of student climbers is a process of conceptual thinking, because the five indicators fulfilled in each problem lie in the same type of thinking process.

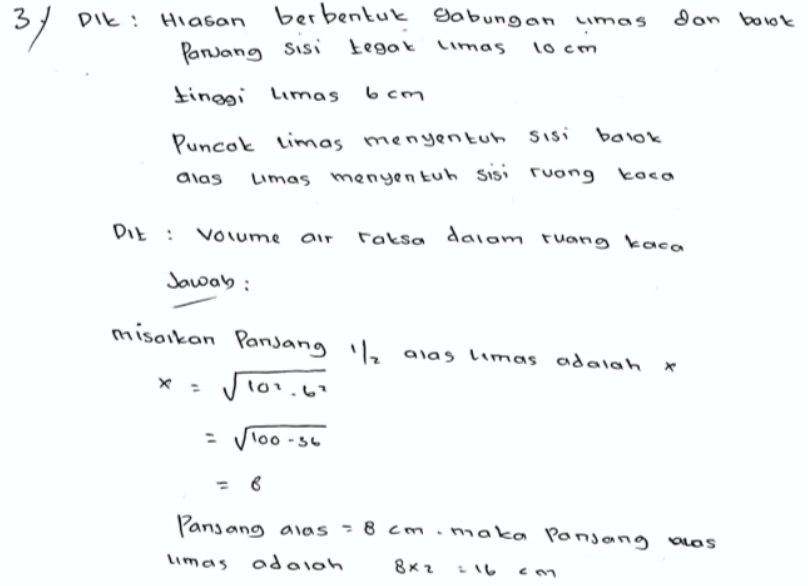

Fig. 12. Students campers answer for equal problems

The results of test analysis and interviews of campers students showed the first problem fulfilling the indicator: being able to state what is known in the problem with their own language or change it in mathematical sentences (B1.1), able to express what was asked in the problem with their own language or change it in mathematical sentences B1.2), able to make a complete settlement plan (B1.3), able to state the steps taken in solving the problem using the concepts that have been studied (B1.4), and being able to re-examine the truth or correct errors from each step of completion so that the correct result is obtained (B1.5). For the second problem fulfilling the indicator: able to state what is known in the question with its own language or change it in mathematical sentences (B1.1), able to express what is asked in the question with its own language or change it in mathematical sentences (B1.2), less able make a complete settlement plan (B2.3), unable to state the steps taken in solving the problem using the concepts that have been studied (B3.4), and are unable to examine or correct the solution made (B3.5). As for the problems of the three campers students meet the indicators: able to express what is known in the problem with their own language or change it in mathematical sentences (B1.1), able to express what is asked in the problem with their own language or change it in mathematical sentences (B1.2), unable to make a complete settlement plan (B3.3), unable to state the steps taken in solving the problem using the concepts that have been studied (B3.4), and unable to examine or correct the solutions made (B3.5)

Based on the indicators fulfilled and guided by the classification of student thinking processes, the thinking process of campers students is inconclusive, because the five indicators fulfilled in each problem do not lie in one type of thinking process that is the same.

\section{CONCLUSION}

Based on the research and discussion results, it was concluded that: the thinking process of MTsS Darul Hikmah students based on adversity quotient varies: students in the climbers category are 3 out of 53 students who have conceptual thinking processes, while students in the camping category are 27 of 53 students who have conceptual, semiceptual, or computational thinking processes. 


\section{REFERENCES}

Agustian, A. G. (2001). Rahasia Sukses Membangun Kecerdasan Emosi dan Spiritual ESQ: Emotional Spiritual Quotient Berdasarkan 6 Rukun Iman dan 5 Rukun Islam. Jakarta: Arga Publishing.

Ahmadi, A. (2003). Psikologi Umum. Jakarta: PT Rineka Cipta.

Dahrim. (1993). Workshop Matematika. Jakarta: Depdikbud.

Effendi, L. A. (2012). Pembelajaran Matematika dengan Metode Penemuan Terbimbing untuk Meningkatkan Kemampuan Representasi dan Pemecahan Masalah Matematis Siswa SMP. Jurnal Penelitian Pendidikan, 13(2), 1-10.

Herawati, S. (1994). Penelusuran Kemampuan Siswa Sekolah Dasar dalam Memahami Bangun-bangun Geometri. Universitas Negeri Malang.

Hoffer, A. (1981). Geometry is more than proof. Mathematics Teacher, 74(1), 11-18.

Komariah, K. (2011). Penerapan Metode Membelajaran Problem Solving Model Polya untuk Meningkatkan Kemampuan Memecahkan Masalah Bagi Siswa Kelas IX J di SMPN 3 Cimahi. Prosiding Seminar Nasional Penelitian, Pendidikan Dan Penerapan MIPA, Fakultas MIPA, Universitas Negeri Yogyakarta, 1.

Krulik, S., \& Rudnick, J. A. (1995). The New Sourcebook for Teaching Reasoning and Problem Solving in Elementary School. Boston: Allyn and Bacon.

Lenchner, G. (2005). Creative Problem Solving in School Mathematics. New York: Glenwood Publication Inc.

Masfingatin, T. (2014). Proses Berpikir Siswa Sekolah Menengah Pertama Dalam Menyelesaikan Masalah Bangun Ruang Sisi Datar Berdasarkan Teori Van Hiele. JIPM (Jurnal Ilmiah Pendidikan Matematika), 3(1), 1-8.

Mayer, R. E., Sims, V., \& Tajika, H. (1995). Brief note: A comparison of how textbooks teach mathematical problem solving in Japan and the United States. American Educational Research Journal, 32(2), 443-460.

Miles, M. B., \& Huberman, A. M. (1994). Qualitative data analysis: An expanded sourcebook (Second Edi). United States of America: Sage Publications.

Moleong, J. L. (2016). Metodologi Penelitian Kualitatif (Edisi Revi). Bandung: PT Remaja Rosdakarya.

Muldash, M. P. (2011). Pengembangan Modul Matematika Kontekstual Materi Bangun Datar Kelas V SD. Universitas Negeri Surabaya.

Nashori. (2007). Adversity Quotient: Hambatan Menjadi Peluang. Jakarta: PT Grasindo.

Polya, G. (1973). How to Solve It : A New Aspect of Mathematical Method. Princeton University Press: Princeton University Press.

Stoltz, G. P. (2007). Adversity Quotient: Mengubah Hambatan Menjadi Peluang (Hermaya, Ed.). Jakarta: PT Grasindo.

Ulya, H. (2015). Hubungan gaya kognitif dengan kemampuan pemecahan masalah matematika siswa. Jurnal Konseling GUSJIGANG, 1(2), 1-12.

Winarso, W. (2014). Membangun Kemampuan Berfikir Matematika Tingkat Tinggi Melalui Pendekatan Induktif, Deduktif dan Induktif-Deduktif dalam Pembelajaran Matematika. Eduma: Mathematics Education Learning and Teaching, 3(2), 95-118.
Zevenbergen, R., Dole, S., \& Wright, R. J. (2004). Teaching Mathematics in Primary Schools. Sidney: Allen and Unwin.

Zuhri, D. (1998). Proses Berpikir Siswa Kelas II SMP Negeri 16 Pekanbaru dalam Menyelesaikan Soal-Soal Perbandingan Senilai dan Perbandingan Berbalik Nilai. Universitas Negeri Surabaya. 